\title{
Doing Masculinity in a Mental Hospital
}

by Ophra Leyser

Dept. of Sociology

Fraser Hall 716

University of Kansas

Lawrence, KS 66045

Email: oleyser@,ku.edu

Keywords: masculinity, identity, total institution, resistance, the body 


\begin{abstract}
This ethnographic study explores how men constructed and enacted masculinity in a total institution. I observed residents in public areas in two branches of a mental hospital in an urban area in the Midwest. I found that the residents at the hospital adhered to gender ideologies found in larger, Western cultures. The structural constraints at the hospital, however, hindered the men from doing masculinity in ways granted to men in the "outside world." The male residents found alternative means to maintain their masculine status through the only resource they had: themselves.
\end{abstract}




\section{AUTHOR'S NOTE}

I would like to thank Kristen Myers for her help in developing these ideas, along with Carol Warren, Joey Sprague and Bob Connell for their helpful comments. 
Introduction

The social constructivist view of gender presents gender as a set of expectations for what people are like and how they will act. For example, men are expected to emulate a hegemonic masculine ideal that emphasizes positions of authority, strength, and the accumulation of material goods (Connell 1987). Simply possessing these characteristics, or goods, however, is not sufficient to establish a masculine identity. Gender is also a performance, people must do gender (Kessler and McKenna 1978; West and Zimmerman 1987). Doing gender implies an interactional process whereby men and women simultaneously display gender and obtain knowledge about what is an appropriate gender display for each particular context.

How men do gender depends in part on the resources available to them. For example, coming from relatively privileged statuses, men in the men's movement can afford to take weekends off and construct an alternative world out in the woods (Schwalbe 1996). Other men have a different set of resources available to them and these differences create a masculine hierarchy. The form of masculinity that has hegemonic status in Western societies assumes the resources and lifestyle of economically and racially privileged men. Of course, few men can achieve hegemonic masculinity. Men who lack some key resources enact other, less socially valued, forms of masculinity. For example, working-class or unemployed men are more destructive to their bodies through the use of alcohol and heavy drugs or other risky behaviors (Connell 1987, 1995), macho presentations by gay men are responses to their feminized stigmas (Kleinberg 1995), and some black men take on a "cool pose" as compensatory masculinity (Majors and Mancini Billson 1992, 2). 
Context also influences what resources men (and women) have or do not have, as seen in studies on gendered organizations (Acker 1990; Britton 2000; Moss Kanter 1977). My study also focuses on the interactional aspect of gendered behavior under the constraints of organizational structure. A total institution provides a stringent test of the "gender-as-process" theory as it helps us see more clearly the processes operative wherever people lack certain resources. Compared to the various settings found in most people's lives, the resident's life in a total institution is fully contained. The total institution exerts almost complete control over residents' lives: their actions and words (i.e., eating, sleeping, leisure, talking, work) are monitored and often documented. The resulting lifestyle is extremely routinized and scheduled, allowing little individual freedom. There are timetables for all activities, which are highly regulated and follow a rational plan designed to fulfill the official aims of the institution. Furthermore, the resident is surrounded by others in a similar situation so that the institution is central to almost all people with whom the participant has sustained interactions (Diamond 1992; Foucault 1984; Goffman 1961; Scholinski and Adams 1997; Shield 1989; Szaz 1970; Tisdale 1987).

The restrictions set by the institution are both material, such as doors, and also ideological, such as values and norms. Some doors are locked, blocking access to staff rooms. There can also be no doors to a dorm room, inhibiting any resident privacy. A minority of the people has the authority to uphold the interests of the institution, interests that do not necessarily correspond to those of the residents, creating social distance between those with and without power. For example, the staff in a mental institution assumes that residents are indeed insane; this prognosis may or may not be agreed upon 
by the residents (Rosenhan 1973) yet the residents are relatively powerless to redefine their sanity. The amount of power over the residents is so extreme that they must get permission to do or obtain even the simplest of things.

The gendered ideologies implicit in the structure of a total institution are dominant ideologies affecting resident lives. It is these ideologies that residents must acknowledge, maintain, or redefine. The passivity required of residents fits more closely with enactments of femininity and goes against stereotypical masculine behaviors. As such, the question I ask is: what do men in a mental hospital do when they are almost totally deprived of the usual props and settings for doing some form of hegemonic masculinity?

Methods

\section{$\underline{\text { Settings and Population }}$}

After obtaining permission both from the university and mental hospital review boards, I spent four days a week, for three months during the summer of 1997 collecting 217 single-spaced, typed pages of field notes in two different settings at Marion Center Mental Health Facility ${ }^{1}$. My data come from observations of approximately 50 residents; there were specifically 23 men and 17 women who were active and thus "regulars" in my field notes. I also observed about 25 staff in their interactions with the residents. I did not observe resident-staff interactions in clinical settings; I mostly saw interactions between technicians and residents (these are the majority of staff interactions that residents have in their daily routines) and teachers and residents. There was a gender hierarchy in the staff structure; there were twice as many women than men as technicians 
and teachers whereas the men were found in more administrative and psychiatric positions. With these sex-typed jobs the majority of staff that I saw interacting with residents were women.

Most of the residents in the study were involuntarily committed and diagnosed with moderate mental illnesses such as schizophrenia or personality disorders yet were maintained at functional levels on their medications. Most of their diagnoses were not tied to gender inappropriate behavior. Given the diversity of diagnoses and the similarity of gendered behaviors among many residents, I do not believe that their enactments of gender were largely due to their illnesses. They were not too detached from reality to be helpful for my study yet they had been in the hospital long enough to feel the effects of the institutional structure. Two-thirds of the residents were white and almost all of the residents grew up in working-class areas around a major metropolitan area in the Midwest $^{2}$. Furthermore, about two-thirds of the residents' fashion choices were indistinguishable as most wore similar casual clothing although some of the women had purses. The other one-third of the residents were at extremes and either paid more attention to fashion or less and had somewhat disheveled appearances.

I was in the first setting, "Ashton," between $11 \mathrm{am}-1 \mathrm{pm}$. Ashton contained two dorms, one for women and one for men. Each dorm was filled with two-person rooms with no doors. The dorms were on the ends of a long, straight building with an adjoining dayroom in the middle. A cafeteria, an isolation room, a staff booth and staff offices were attached to the dayroom. The bathrooms were segregated for three groups: male residents, female residents and staff irrespective of gender. The unit also had a TV/activity/group session room that was in the entrance to the female dorm. The 
majority of the time spent at Ashton was unstructured. A few sessions or activities and mealtimes were the only structured times during the course of a day.

Between 1-3pm I was in the second setting, "Spectrums." This was a building that housed a rehabilitation program, providing numerous classes and skill training to help residents prepare for community living. Only residents who were candidates for release attended classes. Residents from different units, including Ashton, came to Spectrums for four hours a day: two in the morning and 2 in the afternoon. Each class lasted one hour and had 5-8 students.

Virtually all time at Spectrums was structured. There were numerous classes offered on life or vocational skills including learning about different cultures, spelling and vocabulary, finding information in a newspaper, cooking and cleaning, budgeting money, sewing and craft-making, planting a garden and raising houseplants, patronizing restaurants and using public transportation. There were also ceramics, silk-screening, computer and music classes offered. Men were in the minority of the male-to-female ratio in only 5 of the 28 classes that I observed. Residents had little choice in what types of classes they could take yet those with adequate skills in most of the above mentioned classes were also offered at least one hour of "workshop" subcontracted through local businesses. The residents were paid a small amount of money in exchange for their physical labor. Examples of tasks at workshop include folding boxes for filters, packing and unpacking CDs, and weighing and packing nails.

The major difference between Ashton and Spectrums, structured versus unstructured time, provided an opportunity to see resident behavior under varying conditions and restrictions and thus the impact the structure of the institution had on 
individuals. In the highly regulated setting patients were more closely monitored and the structure was made explicit through rules about remaining seated, staying on task, and not speaking out of turn. In the less regulated setting individuals had more liberty to express themselves, evade hospital rules, and create their own norms.

Resident behavior toward me was different in each setting, partially because of different entry styles ${ }^{3}$, yet mainly because of the structure of the setting. Structured time gave clients explicit guidelines and set tasks to follow. In contrast, nothing specific had to be done during unstructured time. Clients utilized this time to pursue hobbies or play with rules and norms, seeing what they could and could not get away with. The fact that I became more noticed in this setting is not unusual. People react to the observer based on her or his personal characteristics (Mrivis and Louis 1985), and I believe being young and female made me a target for heterosexual men to assert their male dominance. I integrated this information into my field notes and analysis.

The ability to observe and talk to some of the same residents in both Spectrums and Ashton proved to be quite useful. I was able to follow the same people into different settings, allowing me to see how the difference in structure and people within the setting affected resident behaviors.

\section{$\underline{\text { Data Collection and Analysis }}$}

In order to analyze my field notes, I employed what Glaser and Straus (1967) coined "grounded theory." Although there is no orthodoxy involved in grounded theory, it is suggested that one concentrates on a process, "a single activity, preferably one which can be expressed as a gerund: negotiating, encountering..." (Turner 1981, 347). Once a 
process is chosen for analysis, it becomes the central concept and the researcher must examine it in full (Turner 1981). Although I took notes on as much as I could observe, the process on which I concentrated was doing gender. As a first step I coded the first half of my data looking for similarities/trends in order to summarize the large amounts of information. I then developed concepts in order to theorize why I was finding these trends. Next I checked my developing ideas against the rest of my data for clarification and validation. Last, I attempted to fit my data into larger theories on gender and organizations.

I tried to reduce researcher bias in several ways. My copious pages of field notes were to neutralize some subjectivity in reducing the possibility of selective perception (Fonow and Cook 1991). Furthermore, instead of assuming that I am an objective scientist devoid of emotion, I wrote down my feelings in my field notes. There were a couple of instances where I felt sad but I ended up not using this data. I also noted how being a woman strongly affected how the residents interacted with me (such as flirtation from men). Last, at the preliminary analysis stage I wrote many "spew" drafts in order to flesh out concepts and to investigate my own subjectivity (Glesne and Peshkin 1992).

\section{Gendered Life at Marion Center}

Upon admission to Marion Center people were stripped of their identities by being subsumed under a generalized patient identity also seen in other institutional literature (Diamond 1992; Goffman 1961; Scholinski and Adams 1997; Tisdale 1987). This stripping was both ideological and material ${ }^{4}$ and was accomplished by the withdrawal of resources. Retaining some semblance of self was difficult, especially for 
certain identities previously attached to work and family roles. The residents did find, however, that they could maintain some types of gendered identities.

The men at Marion Center, similar to residents in other institutions, did not have the power to define themselves as authority figures in the staff-resident hierarchy of the hospital ((Foucault 1984; Gittins 1998). They were subordinated to both male and female staff and could do little to challenge this structure due to the strictly enforced rewardpunishment system. In the interactions that I observed the male residents behaved similarly in the presence of male and female staff. Most of their daily contact with staff was with women; the residents knew this arrangement as the authority structure.

As Johnson (1998) also documented, residents form relationships and a social structure that does not involve staff and it is these types of relationships that residents have some control over. It is through this resident hierarchy that the men at Marion Center continued to reinforce the idea of hegemonic masculinity found in larger culture. The hierarchy was maintained for several reasons. First, residents brought ideas from the "outside world" into Marion Center with them, such as the idea that being gendered is being "normal," and normalcy was a much needed feeling for many of these residents. This lifetime of exposure was then reinforced through media sources such as a variety of magazines such as Vogue, car magazines, and National Geographic in the dayroom at Ashton and in the library and workshop at Spectrums. They would also spend every evening watching popular network television shows. Last, the structure of the hospital reinforced gender separation among residents, and thus the idea of gender dichotomization, through rules and actual architecture that segregated the sexes such as 
separate restrooms for male and female residents but unisex bathrooms for staff at Ashton.

Last, the staff in Marion Center also upheld gendered beliefs in several ways. First, they reinforced the idea of dichotomizing and making note of people's sex. For example, Betty told Ric that he picked a team of "ladies" for the basketball game. The residents take note of this language. In her second ceramics class of the day Fanny talks about the birdbath that the girls made last hour. In a conversation later on Luke asks, "You didn’t call when the girls were here last hour?"

Staff also upheld gendered beliefs by reinforcing gendered behaviors. At Ashton Peter gave his chair up against the wall for an elderly woman who usually sat against another wall. The woman staffer said, "A gentleman gave you his chair.” Comments like these also came in the form of negative statements. Betty said to a male resident who kicked a female resident's chair: "That's not a way to treat a lady!" Although Betty was well-liked and generally amiable towards residents, she still had authority over them. What staff believed was acceptable gender behavior was rewarded, what they deemed inappropriate gender behavior was punished.

Rewards and punishments for gendered behaviors are found in many settings (Acker 1990; Costrich et al 1975; Dunn and Skaggs 1999; Hartmann 1993; Hochschild 1983; Jackman 1999; Jones and Remland 1992; Lips 2000; Ridgeway 1997; Ridgeway and Smith-Lovin 1999) and in this case the staff members' beliefs about how men should treat women became structurally legitimated through their position of authority. Staff reinforced gendered behaviors because they were still exposed to normative gendered 
ideals both in the hospital and outside of the hospital when they left their workplace and entered the "outside world ${ }^{5} . "$

Even given these multiple agents of gender socialization, many of the gendered interactions were perpetuated by the residents themselves. Both men and women do masculinity and femininity to some extent, but the focus of this study is on a masculinity that was both very important and attainable if pursued aggressively. Enacting femininity, on the other hand, was subtler because it required passive and dependent behaviors built into the patient role. The male patients used verbal and non-verbal displays to uphold the masculine hierarchy in reference to other men, in reference to women and even in reference to themselves (Kaufman 1987; Mason-Schrock 1996; Schwalbe and MasonSchrock 1996). It is these interactions that are the focus of the following sections of this paper.

\section{Enacting Masculinity Verbally}

Language can be a powerful tool for exerting dominance in any situation (Smith 1990) and this section highlights how the men at Marion Center took advantage of the fact that they still had this resource in certain contexts. Especially during unstructured and less supervised time they had the capacity to challenge others through positive selfdefinition or pejorative statements directed to others. In structured time the men did enact masculinity verbally yet in a more restricted (i.e. fewer swear words, less explicitly crude sexual content) fashion because they were almost in constant earshot of the teachers. 
Residents were not given much time to interact in one-on-one or small group settings and as a result large audiences were inescapable. Women were often the topics of conversation directed to a general audience. The male residents turned women into objects or props in front of an audience, much as women are objects of harassment in public areas in the "outside world" (Bowman 1993, Gardner1995). For example, one day at Ashton a young woman named Heather came out of a room wearing a tee shirt that came down to her mid thigh. Aaron asked, “Are you wearing underwear?" He did not say this statement loud enough for Heather to hear, possibly because she was next to the staff booth and Aaron did not want the staff to hear his sexualized comment. In any case, Aaron made his statement easily audible to those in his close vicinity.

In other cases men's comments were directed to certain women. One day in the dayroom in Ashton Aaron proposed to a woman that she "come sit here" and then started singing, "Do you wanna dance, make romance." Rarely were the men concerned with women's reactions or lack of reactions to statements that they made about specific women or women in general. The sexualized talk about women was for the benefit of the men around them. Sexuality can be used as a means of resistance (Foucault 1978) and in this case an assertion of heterosexuality granted status in the masculine hierarchy.

\section{The Sexually Objectified Woman}

Gender was done verbally through the use of a public forum and this in turn created shared meanings. For some of the male clients, gendered statements served a specific purpose for the communicator: he "proved" himself to be a "regular" man 
because striving for normalcy was especially pertinent for people that were stigmatized as "insane."

Such proof was based on using women as "symbols of success" (Pleck 1995, 9) such as having a girlfriend or from drawing upon more abstract, cultural representations of resources as seen in the following example. Nathan, as an elderly man was doubly challenged in doing masculinity as he was both a mental patient and old, both of which are culturally defined as non-sexual (Howard and Hollander 1997). In making sexual references to women, Nathan compared himself to a powerful cultural icon:

A group song was sung at Ashton:

Nathan (sitting next to Kim): 'I'm Popeye the sailor man...'

Two men: 'toot toot' (noises)

Sig continues the jingle: 'I live in a garbage can.'

Nathan takes it over: 'I love to go swimmin' with long-legged women, I'm Popeye the sailor man.'

Eldon laughs.

Not only was this song associated with an older generation's history, the protagonist also shared some of his attributes. Popeye was an older man, an otherwise small and not powerful man until he ate his spinach. The elderly man that sang this song was eating his spinach — he was accessing masculine power by objectifying women and getting group acknowledgement to make up for his own lack of immediate resources.

Kim, Nathan's neighbor, did not react to the Popeye song; women's reactions to sexist language were usually minimal. Perhaps an argument was risky because residents got reprimanded from staff for fighting. Another reason for minimal or no response was 
that the female residents were enacting a femininity that was "normal," one where women are passive. The staff seemed to be accepting of this as none ever told a woman to stick up for herself.

Last, the ideas brought forth in these types of statements seemed normal to both the staff and the residents so no objections from anyone were made. Not only are there no objections, but sometimes these statements are made light of by residents or staff. For example, there was talk in a ceramics class about selling the pottery.

Luke: Sell me some women too. Miller. Sell Valerie [his girlfriend].

Fanny (staff): Can't sell people.

Luke and Belinda laugh.

The relative silence of women enabled the men to continue their enactments of masculinity. This "masculinity-validating power" (Pleck 1995, 7) requires women to play their prescribed roles. In fact, the Popeye song started a process of other stereotypic songs:

Jack sings: 'What's your name, little girl, what's your name...took all my American Express...'

This song is another use of a cultural representation of an important resource for doing masculinity—credit cards and money. Furthermore, this song focused on the stereotype of women using men and spending their money frivolously. Jack also made a similar statement earlier that both sexualized women and placed himself in a dominant sexual position as it was about strippers and prostitutes taking his money. 
A young male resident named Luke gives some other examples of the sexual objectification of women. He perpetually talked about multiple girlfriends and women in general. Some of his statements were directed at specific women. In a ceramics class, Fanny (staff) told the class about their fall project. She drew a picture of a cornucopia on the chalkboard and asked the class how they could make a ceramic replica. Luke made a frame with his hands by putting his two extended thumbs together at a $180^{\circ}$ angle and raising his forefingers. He then looked at the board as if he were exactly measuring the picture. The class laughed and Luke said, "Get Valerie [his girlfriend] and tell her to stand and pose."

In this scenario, Luke took a conversation that did not have obvious references to sex or gender and turned it into a statement that not only focused on women but also reinforced current gender ideals such as focus on the female body (Bem 1993). Although ceramics class was structured, these statements were not seen as aberrations or misbehavior. The instructor, Fanny, even teased Luke about his multiple girlfriends: Luke: 'I'm gonna stop by my girlfriend's house.' Fanny (staff): 'Luke's such a flirt. You have more girlfriends than I do friends.'

Luke talked about women constantly, perhaps in order to seem like a "real man," especially because he had other traits that could put his masculinity in question, such as a small body or the stuffed animal that he occasionally carried around. Both he and the staff socially constructed his incessant "woman talk" to be "natural guy" behavior. Other "macho talk" that was not specifically directed to or about women was also constructed by both residents and staff as "natural guy" behavior. 


\section{Men and the Heterosexual Standard}

There were many conversations about a multitude of topics among residents and staff and among residents themselves. There were certain types of conversations, however, that kept reemerging. "Macho" language was an avenue for men to exert superiority over other men and although staff would interject objections to this language at times, especially if it became insulting, they did not exert much pressure to end the confrontations. There was macho talk such as Sig talking to a male friend about how "Evil Knevil breaks his bones, it makes him stronger." A recurrent theme in the macho language, however, was heterosexuality as it was, and still is, conflated with masculinity both in and outside the hospital (Connell 1987; Mosher 1991). In reference to other male residents, the statements functioned either to prove one's own heterosexuality and exert superiority in the masculine hierarchy, or to question someone else's sexuality, thus lowering the other's status on the hierarchy (and raising one's own status).

Macho statements could be general, such as John talking to Len in workshop about how he was disgusted when a man once asked him if he wanted to "get physical." Otherwise macho statements were directed at two types of men. The first were "easy targets" for mockery because of their "wimpiness." The second group of men was more "masculine" and more elite. A successful challenge to either group could lead the challenger to a higher rung in the masculine hierarchy. An argument at Ashton illustrates the negotiation of gender among more "masculine" men:

Jack, a tall man with a big frame argues loudly with another man.

'You homosexual faggot!' 


\section{'Pervert.'}

'Raper, whore-monger.'

A black male staff in his early 30's says: 'Come on guys.'

James: 'Uh oh spaghettios.'

One of the fighters: 'I'm a _ ?' (I could not hear the word used).

James: 'I'm a _?'

Jack: 'Like I never fucked a girl. I was a hard working citizen. Got coffee at

Denny's. Damn bitches at damn bars took all my money. Strip clubs, whore

houses, took all my damn money.' (He hacks and makes spitting noises.)

Jack yells at Wyatt: 'Homosexual faggot.'

Wyatt is on the other side of the room: 'Homosexual faggot.' (he laughs) 'Shut the hell up.'

Jack: '...suck dick, you homo'

Sig: 'Silly mother fucker...Michael Jackson.'

Jack: ‘...jackoff...’

The argument fades now and the men remain silent.

As the argument progressed, the men strove to find worse insults because a successful counterattack was one way to invalidate a negative identity (Howard and Hollander 1997). The negative identity that these men were most concerned with was that of a gay person. At the zenith of the argument, during the most heated moments, homosexuality emerged as the worst possible epithet. These men resorted to using anti-gay language as a way to demean other men for not being heterosexually active. The accusers themselves 
may not have been heterosexually active, but they had to show that if they could, they would have heterosexual relations.

Other sexual aberrations were also addressed as someone "wimpy," or lower on the hierarchy, got harassed at Ashton:

Sig drops his Walkman and gets angry with Peter: 'Don't tell me what to do. Go fuck your mattresses.'

Medical technician: 'Hey Sig.'

Sig: 'That's what he does all day. Perverted.'

Sig's insults referred to sexuality outside of male-female intercourse. Private masturbation was seen as sexual deviance and not a way to prove one's sexual prowess, similar to views held by the general public. A strict heterosexually active ideal had to be maintained, either physically (i.e. having a girlfriend) or verbally to enforce the gender hierarchy upon which male residents relied.

\section{Enacting Masculinity Nonverbally}

Language was not the only resource for doing gender. The men at Marion Center had one other site of resistance, their bodies. They used their physical force/bodies for the same purposes as their vocal cords: to prove to themselves and other residents that they had masculine status in the resident hierarchy. The use of touch was mainly reserved for other residents as staff strongly enforced a no-touch rule between staff and residents. As such, touch, for the male residents, was an indicator of status ${ }^{6}$. Those with 
more authority had more autonomy to touch others. The majority of the touching at Marion Center was observed either at Ashton or during more unstructured time at Spectrums when the residents were not expected to be sitting quietly. Two-thirds of the touching was done by men and of these half were male-to-female sexual touches and a quarter consisted of male-to-male roughhousing that displayed both strength and an avoidance of sexual overtones. The last quarter was mostly male-to-female non-sexual touch and then there were a few instances when male-to-male touch could have been construed as sexual.

\section{$\underline{\text { Male-to-Female Touch }}$}

Half of the male-female touching at Marion Center was either implicitly or explicitly sexual. Some of this touching was also done by multiple men to one woman at the same time. For example, in Ashton Aaron put his arm around a woman's shoulders and then Sig did the same thing on her other side. Even if the men were not touching women at the exact same time I believe that the men watched each other to see which women would accept being touched. For example, at different times, Aaron and John whispered to Heather in the Ashton dayroom while they put their hands on her back. Heather passively accepted advice and touching, she hardly talked. I believe this was what Aaron and John liked about her: she would neither talk back to them nor tell staff that she had been touched.

Heather capitulated to male touches perhaps due to the assertiveness and persistence of some of the men. Even Lana, who was not as passive as some of the other female residents, finally gave in to unwanted male attention. Lana was a little rough and 
belittled other male and female residents, and chose to avoid a completely "feminine" appearance. When she wore long flowing skirts, she would also wear gym pants underneath accompanied by her high-top basketball shoes. One day in workshop some residents were waiting by the door at the end of the hour. A male resident smiled and hugged Lana. She turned away from him to talk to some others but he tapped her on the back repeatedly and when she finally turned around he forced a hug on her.

Male residents also touched me quite a few times on my hair, my arm, my leg and my breast when I was sitting next to them during unstructured time. The men would try to surreptitiously touch me to avoid being caught by staff. The motives behind these touches could be multiple. These men were proving their sexuality to themselves and to each other by focusing attention to the reactions of other men; trying to impress me was not their only objective. They knew that I was "off limits" as a reciprocal partner and that I was not a permanent part of their lives; I represented a generalized woman. The active audience that did count consisted of the semi-permanent members in the settingother male residents. These men lived with one another for an indefinite period of time, so the struggle for "superior" masculinity between them became a primary objective for improving their sense of self through the upkeep of a male identity.

Perhaps a secondary reason for touching me was that, given the lack of opportunities for more intimate sexual experiences, touching a woman was a significant sexual experience. Not every man had this opportunity, so those seeking some amount of intimacy took whatever opportunity they could get. Furthermore, exhibiting sexuality was a way to break from the asexual standards at Marion Center. Rebelliousness was 
taking initiative, feeling that there was some freedom of action to take against the hospital restrictions.

Why I was chosen as a target was clear: the men quickly learned that I would not respond negatively or positively. This allowed them to be the agents. They also felt safe in expressing themselves because they knew that I would not tell staff. At one point I moved my seat away from Perry, a frequent toucher, after he scooted his chair close to mine. He noticed my move and asked if he could sit by me. I answered, "Yes, if you don't touch me." At this statement he got up and left- he had no passive recipient. Perry was not interested in talking to me; he wanted me to be an object to enable him to assert his sexuality/masculinity. Without a woman, Perry could not exhibit his sexuality in a manner acceptable to the Marion Center males.

\section{Male-to-Male Touch: Roughhousing}

In reference to other men and using other men as their props, one avenue for displaying masculinity was male-male touch. Some of this was "bonding" behavior.

After gym class Ric slaps Rock's hand, they talk.

Rock: That's cool man.

At Spectrums Rusty holds the door open for people to walk into the building. As Sam walks through the doorway he slaps Rusty’s bicep in a friendly manner.

Other male-male touch was more along the lines of roughhousing, or play fighting. 
In between library activities Rusty squeezes Luke's bicep as a test of his strength.

He then pulls Luke's arm hair and then squeezes his hand hard.

In the dayroom in Ashton Roy has another guy in a neck, then arm lock.

Waiting for class outside of Spectrums, Al has a shirt in his hand. Cobb takes it and hides it. $\mathrm{Al}$ and Cobb joke around and Cobb play punches $\mathrm{Al}$ on the bicep.

I use the term "play fighting" to signify that a large amount of force was not used, meaning that these men were not causing each other physical pain. However, this "playing" was actually work in the sense that these men were engaging in identity work, fortifying their masculine images.

The use of roughhousing in Marion Center paralleled the use of roughhousing in masculine domains in the larger American society (Martin and Hummer 1996). The valuation of "toughness" and the strong feeling of homophobia (Connell 1987; Schwalbe 1996) combined to create an atmosphere where play fighting became the only acceptable outlet for public touching between men. In the above examples, men who would be considered masculine by traditional standards were doing the roughhousing. Roy was a tall man, especially compared to his "friend" in the neck and arm locks. Rusty was a large, strong, young man interested in auto mechanics. Cobb, although small in physique, was a young cowboy— he wore a cowboy hat and actually came from a cattle ranch. These two men were also very mentally coherent, not something every man in this 
setting could claim. Given these more "masculine" characteristics, roughhousing was a socially acceptable outlet.

Another resident found that roughhousing was not the only way to avoid a homosexual label if engaging in male-male touch. Stuart gave another man a back rub in the dayroom in Ashton. He then moved to a nearby chair where a woman was sitting and also gave her a back rub. After the woman's back rub, Stuart returned to the first man and spanked him, once, hard on the buttocks. Stuart was either very physically expressive or he could have been more interested in touching men. His exact intentions were unclear, nevertheless, Stuart avoided any teasing because touching a woman in the same context neutralized any implications that touching the man was a homosexual advance.

There was also the instance of Billy, who was joking with Aaron in the dayroom of Ashton. Billy was around 40 years old. He had a scraggly beard, a flannel shirt, his jeans were falling below his waist and he had ruffled orange hair. He looked like a mountain man. He put his arm around Aaron briefly and said: "Baby." Aaron laughed at the obvious poke at male-male fondness. At a later time Billy picked Aaron up from behind and put him down quickly:

Billy: 'How much do you weigh?'

Aaron: '240.'

Billy: 'You don't weigh 240!'

Aaron laughed at the cutesy talk but did not laugh when roughhousing was involved. Roughhousing was a signifier of physical strength and on the exterior it was to be taken with levity, yet conforming to the male-male touch behavior was a serious issue if one 
was to engage in masculinity work. The proper responses to roughhousing were either reciprocal roughhousing as a show of strength (i.e. comparing strengths) or a more passive acceptance of the behavior, acknowledging that one could "take the pain," or perhaps a capitulation to the other's superior strength.

The staff also supported the construction of male-male touch as joking rather than sexualized behavior. A caseworker, Margaret, emerged from an office attached to the dayroom of Ashton and saw a man patting Aaron's belly. Margaret: "Playing babaloo on your stomach?" Aaron then sang a song with the word "babaloo" in it. Male-male touching was a common event but in order to work it had to have the appearance of a joke. Anything serious might have been construed as non-masculine, meaning feminine or homosexual, both of which were problematic for both residents and staff.

\section{Self-Touch: Masturbation}

In reference to other men and using women as objects, public masturbation was another avenue to display one's sexuality and the subsequent "manliness" equated with heterosexuality. Although public masturbation can be seen in many contexts as fairly deviant behavior, here it can be seen as a "secondary adjustment" to get around the organization's assumptions of what a resident should be (Goffman 1961, 107).

I observed several instances of masturbation both in Ashton and Spectrums. For example, in the dayroom in Ashton:

Aaron gets up and sits at chair at table facing me. Stares at me, I glance briefly at him twice. He is touching himself through his shorts. I don't know if he knows that I notice. Aaron plays with his zipper, I don't want to stare at his private area, 
and I don't want him to know that I am looking. I vaguely see from my peripheral view upward stroking movement. Faster pace now. Two other men sit at Aaron's table. David is sitting next to Aaron, facing me and looking at me I am in his full view. I look at them and Aaron stops stroking. I look away. I think Aaron's penis is completely out of his shorts, he continues to stroke up and down. I look directly at his face and he seems not to know or not to care that I know what he is doing. I don't know if others at table notice-- maybe David does. Aaron stops, he gets up and leaves.

Physical gratification did not seem to be the only purpose of masturbation because I never saw physical evidence of orgasm (perhaps, however, medications made orgasm difficult). Contrary to private masturbation, public masturbation was a show of manliness for other men. The men were proving to themselves and to each other that they were sexually capable human beings in that they could "prove" that they were heterosexual; in this case I was merely an object to be used as "proof" that their sexuality was directed at a correct object (i.e. a female).

Aaron being his model, David learned that he could assert his sexuality as well. David decided to take Aaron up on his challenge:

David gets up and sits in the chair that Aaron was in. He begins to touch himself through his sweatpants. A white staff, 40, short blond hair comes out of booth and as she walks by says: 'Stop that right now.' David immediately stops. Another resident asks: 'What?' Staff: 'I was talking to David.' 
David just sits there.

Beyond showing off to me, David was proving his manliness in two ways. First, he was "cock fighting" with Aaron in proving that he too could be a heterosexually functional man. David was also showing courage to other residents as he was facing the risk of getting caught by staff. Aaron and David believed that the benefits from their acts (a macho image) outweighed the possible repercussions (no privileges for a day). I did not witness public masturbation in front of other women, but the staff did not seem to be surprised when they caught these acts, suggesting that they have seen these behaviors before.

\section{Conclusion}

This analysis illustrates the contextuality of gender as it is dependent on structural constraints. Most research on gender is about free populations in the "outside world" (i.e. non-institutionalized). My analysis, however, looked at how gender, more specifically masculinity, was maintained in a total institution. The residents held traditional gendered beliefs and enacted masculinity in some similar ways to outside populations; some behaviors, however, would not be found in other contexts due to the hospital constraints such as a perpetually public forum for all interactions and a limited use of resources for maintaining and performing masculinity. Bodies are both sites of control and subsequently sites of resistance (Foucault 1980); they are also mechanisms to transmit and maintain dominant ideologies (Foucault 1977). The bodies of the men in this study were controlled yet they were also one resource the men had control over in order to 
maintain a gender hierarchy. Both verbal and nonverbal acts were used to prove the heterosexuality that becomes so closely tied to the construction of masculinity both in and outside of institutions (Pleck 1995; Connell 1995).

Gendered norms found in the larger society were very much part of life in the hospital due to several factors. First, the residents' brought their past experiences and beliefs with them to the hospital and interacted with others based, in part, on these beliefs. People have been socialized and part of a gendered world since birth (Weitzman 1979) and these pervasive gender ideologies still persist even if people are not in normative social institutions (Snow and Anderson 1987). Second, the residents were not completely isolated as they had exposure to the "outside world" through media sources, family visits and staff interactions.

Not only did the residents hold normative gender ideologies, but there were also gendered structures and rules within the hospital that were upheld by staff and maintained by all. Marion Center is not an exception; in Scholinski's (1997) personal account of hospitalization she describes how she was formally rewarded for enacting stereotypical gender behaviors such as wearing makeup and dresses and hugging "acceptable" men (i.e. staff). Ironically, although gendered norms existed in Marion Center, the hospital structure posed barriers to enacting masculinity in normative ways. In the "outside world," masculinity is displayed through the use of various roles and props, from important jobs to fast cars and trophy wives; all this is absent from institutional settings. In the "outside world" masculinity is also displayed within a pecking order - the dominance of men over women and each individual man over every other (Connell 
1987). In the total institution this hegemony was challenged where staff were dominant over residents.

Although gender could not be accomplished in some normative ways, gender was still very important to maintain in Marion Center because residents saw gender as one of their primary identities, especially given that many of their other identities had been stripped away, and they were able to control and maintain a gendered identity given their limited resources. Residents were very attentive to their surroundings; they were not so "out of it" that they were not based in a shared reality. They were aware of staff, rules, and other residents; they engaged in identity work and negotiated ${ }^{7}$ their desires as they assessed if they could obtain their wants and how they would act based on their audience. For instance, unstructured time usually created more flexibility of expression, such as more heated verbal altercations and public masturbation.

Given the lack of material resources in the hospital, male residents were forced to draw primarily upon ideological components of gender to assert their gender identities. One way to retain dominance in the hospital was through sexuality. Sexuality, in the larger culture and hence also in Marion Center, is a way of doing gender Hollander 1997). For example, men "should" decide when, whom, and with whom they wanted to sexualize and/or have sex with while women should feel complimented and passively accept sexual advances (Bem 1993). Institutionalization deprived men of a particularly important means of doing masculinity—control over women and other nonmaterial resources, so sexuality became especially salient, both in accusations of homosexuality and in aggressive attempts to assert sexual potency. They mostly used animate props such as non-staff women in order to demonstrate that they were "real men." Other men's 
bodies or the resident's own body were also used to demonstrate masculine authority in the resident gender hierarchy. Most often the construction of masculinity revolved around heterosexuality because the men in Marion Center drew upon one of the few resources that they had: their bodies and their words. 
Notes

${ }^{1}$ All places and names have been given pseudonyms.

${ }^{2}$ Although working class men can exhibit hegemonic masculinity in aggressive ways (Connell 1987, 1995), the men in this hospital did not have resources that working class men in the outside world have such as alcohol and drugs, families, jobs, and cars. As such, their gendered behaviors were largely due to their situation rather than their class. ${ }^{3}$ At Ashton the unit director introduced me saying that I wanted to "talk to" everybody, whereas I introduced myself at Spectrums as an observer.

${ }^{4}$ Material items also have ideological components through the social value attached to them.

${ }^{5}$ Although I did not observe resident interactions with their therapists, there is the possibility that they also reinforced gendered behaviors because Broverman et al (1970) found that what clinicians consider "normal" behavior is gendered and differs for male and female residents.

${ }^{6}$ For women the use of touch was primarily done as a sign of friendship between women.

${ }^{7}$ I do not mean to imply by the term "negotiate" that all parties come to the table with equal resources or bargaining power. 


\section{References}

Abbott, J. 1981. In the Belly of the Beast. New York: Vintage.

Acker, J. 1990. Hierarchies, Jobs, Bodies: A Theory of Gendered Organizations. Gender and Society 4,2:139-158.

Bem, S.L. 1993. The Lenses of Gender: Transforming the Debate on Sexual Inequality. New Haven: Yale University Press.

Bowman, C.G. 1993. Street Harassment and the Informal Ghettoization of Women. Harvard Law Review 34:205-212.

Britton, D.M. 2000. The Epistemology of the Gendered Organization. Gender and Society 14, 3:418-434.

Broverman, I.K., D.M. Broverman, F.E. Clarkson, P.S. Rosendrantz, and S.R. Vogel. 1970. Sex-Role Stereotypes and Clinical Judgments of Mental Health. Journal of Consulting and Clinical Psychology 34, 1:1-7.

Chodorow, N. 1978. The Reproduction of Mothering. Berkeley: University of California Press. 
Connell, R.W. 1987. Gender and Power. Stanford: Stanford University Press. . 1995. Masculinities. Berkeley: University of California Press.

Costrich, N., J. Feinstein, L. Kidder, J. Marecek, and L. Pascale. 1975. When Stereotypes Hurt: Three Studies of Penalties for Sex-Role Reversals. Journal of Experimental Social Psychology 11:520-530.

Diamond, T. 1992. Making Gray Gold: Narratives of Nursing Home Care. Chicago: The University of Chicago Press.

Dunn, D. and S. Skaggs. 1999. Gender and Paid Work in Industrial Nations. In Handbook of the Sociology of Gender, edited by J.S. Chafetz, pp 321-342. New York: Kluwer Academic/Plenum Publishers.

Fonow, M. and J.A. Cook. 1991. Beyond Methodology: Feminist Scholarship as Lived

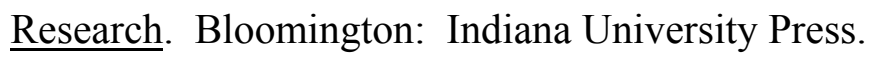

Foucault, M. 1977. Discipline and Punish: The Birth of the Prison. Translated by A. Sheridan. New York: Vintage Books. . 1978. The History of Sexuality, Volume I: An Introduction. New York: Random House. 
. 1980. Body/Power. In Power/Knowledge: Selected Interviews and Other

Writings 1972-1977, edited by C. Gordon. New York: Pantheon Books.

. 1984. The Foucault Reader. Edited by P. Rabinow. New York: Pantheon

Books.

Gardner, C. B. 1995. Passing By: Gender and Public Harassment. Berkeley: University of California Press.

Gilman, C.P. 1892/1992. The Yellow Wallpaper. In Fiction 100: An Anthology of Short Stories, edited by J.H. Pickering, $6^{\text {th }}$ edition, pp 476-487,1431. New York: Macmillan Publishing Company.

Gittins, D. 1998. Madness in its Place: Narratives of Severalls Hospital, 1913-1997. London: Routledge.

Glaser, B. and A. Strauss. 1967. The Discovery of Grounded Theory. Chicago: Aldine.

Glesne, C. and A. Peshkin. 1992. Becoming Qualitative Researchers: An Introduction. White Plains: Longman Publishing Group.

Goffman, E. 1961. Asylums. New York: Doubleday. 
1963. Stigma: Notes on the Management of Spoiled Identity. Englewood Cliffs, NJ: Prentice Hall Inc.

Hartmann, H. 1993. Comment on Brines and Fiorentine. Rationality and Society 5:375385.

Hochschild, A.R. 1983. The Managed Heart: Commercialization of Human Feeling. Berkeley: University of California Press.

Howard, J.A. and J. Hollander. 1997. Gendered Situations, Gendered Selves. Thousand Oaks: Sage Publications.

Jackman, M.R. 1999. Gender, Violence, and Harassment. In Handbook of the Sociology of Gender, edited by J.S. Chafetz, pp 275-317. New York: Kluwer Academic/Plenum Publishers.

Johnson, K. 1998. Deinstitutionalizing Women: An Ethnographic Study of Institutional Closure. Cambridge: Cambridge University Press.

Jones, T.S. and M.S. Remland. 1992. Sources of Variability in Perceptions of Responses to Sexual Harassment. Sex Roles 27:121-142. 
Kaufman, M. 1987. The Construction of Masculinity and the Triad of Men's Violence. In Beyond Patriarchy: Essays on Pleasure, Power, and Change, edited by M. Kaufman, 665-689. Toronto: Oxford University Press.

Kessler, S.J. and W. McKenna. 1978. Gender: An Ethnomethodological Approach. Chicago: University of Chicago Press.

Kleinberg, S. 1995. The New Masculinity of Gay Men, and Beyond. In Men's Lives, edited by M.S. Kimmel and M.A. Messner, pp 45-57. Boston: Allyn and Bacon.

Lips, H.M. 2000. College Students' Visions of Power and Possibility as Moderated by Gender. Psychology of Women Quarterly 24:39-43.

Majors, R. and J.M. Billson. 1992. Cool Pose: The Dilemmas of Black Manhood in America. New York: Touchstone.

Martin, P.Y. and R.A. Hummer. 1996. Fraternities and Rape on Campus. In Mapping the Social Landscape: Readings in Sociology, edited by S.J. Ferguson, 218-232. Mountain View, CA: Mayfield.

Mason-Schrock, D. 1996. Transexuals' Narrative Construction of the 'True Self.' Social Psychology Quarterly 59, 3:176-192. 
McCorkel, J.A. 1998. Going to the Crackhouse: Critical Space as a Form of Resistance in Total Institutions and Everyday Life. Symbolic Interaction 21, 3:227-252.

Mosher, D.L. 1991. Macho Men, Machismo, and Sexuality. Annual Review of Sex Research 2:199-247.

Moss Kanter, R. 1977. Numbers: Minorities and Majorities. In Men and Women of the Corporation, pp 206-231. New York: Basic Books.

Mrivis, P.H. and M.R. Louis. 1985. Self-Full Research: Working Through the Self as Instrument in Organizational Research. In Exploring Clinical Methods for Social Research, edited by D.N. Berg and K.K. Smith, 320-331. Beverly Hills: Sage Publications.

Pleck, J.H. 1995. Men's Power With Women, Other Men, and Society: A Men's Movement Analysis. In Men's Lives, edited by M.S. Kimmel and M.A. Messner pp 5-12. Boston: Allyn and Bacon.

Ridgeway, C. 1993. Gender, Status, and the Social Psychology of Expectations. In Theory on Gender/Feminism on Theory, edited by Paula England, pp 175-198. New York: Aldine de Gruyter. 
Ridgeway, C.L. and L. Smith-Lovin. 1999. Gender Socialization. In Handbook of the Sociology of Gender, edited by Janet Salzman Chafetz, pp 247-274. New York: Kluwer Academic/Plenum Publishers.

Scholinksi, D. and J.M. Adams. 1997. The Last Time I Wore a Dress. New York: Riverhead Books.

Schwalbe, M. 1996. Unlocking the Iron Cage. Oxford: Oxford University Press.

Schwalbe, M. and D. Mason-Schrock. 1996. Identity Work as Group Process. Journal of Contemporary Ethnography 34:19-26.

Shield, R.R. 1989. The Total Institution. In Uneasy Endings: Daily Life in an American Nursing Home, pp 91-104. Ithaca: Cornell University Press.

Snow, D.A. and L. Anderson. 1987. Identity Work among the Homeless: The Verbal Construction and Avowal of Personal Identities. American Journal of Sociology $82,6: 1336-71$.

Smith, D.E. 1990. The Conceptual Practices of Power: A Feminist Sociology of Knowledge. Boston: Northeastern University Press. 
Szasz, T.S. 1970. Ideology and Insanity: Essays on the Psychiatric Dehumanization of Man. New York: Anchor Books.

Thorne, B. 1995. Gender Play: Girls and Boys in School. New Brunswick, NJ: Rutgers University Press.

Tisdale, S. 1987. Harvest Moon: Portrait of a Nursing Home. New York: Henry Holt and Company.

Turner, B.A. 1981. Some Practical Aspects of Qualitative Data Analysis: One Way of Organizing the Cognitive Processes Associated with the Generation of Grounded Theory. Quality and Quantity 15:225-247.

Wietzman, L. 1979. Sex Role Socialization. Palo Alto: Mayfield.

West, C. and D.H. Zimmerman. 1987. Doing Gender. Gender and Society 1:125-151. 


\section{BIOGRAPHICAL PARAGRAPH}

Ophra Leyser is currently a PhD candidate working in the field of medical sociology at the University of Kansas. 